\title{
Epidemiology of Chagas' heart disease
}

Sociedade de Cardiologia do Estado de São Paulo São Paulo, Brazil

Chagas' disease is a major public health problem in Latin America. About 16 million persons are affected and 90 million others are exposed to the risk of being infected by the parasite. The knowledge of epidemiological aspects of the disease allowed to delineate the strategies for the control of the disease related with the vectorial transmission. However, these strategies have had no priority in all endemic countries. Rural-urban migration in most endemic areas carried infected individuals to urban centers increasing the problem of Chagas' disease by blood transfusion.

In Brazil the control program has reached good results in the last years and in several states the vectorial transmission was controlled.

More recently, hemotherapic practices are performed using screening procedures but this practice must be improved in order to eliminate the possibility of Chagas' disease transmission by another ways (congenital, accidental, oral, etc.).

An adequate health care to the infected persons must be improved in order to diminish the social costs of the severe cardiopathy which has been responsible for the adults premature deaths.

UNITERMS: Chagas' disease. South American Trypanosomiasis. Epidemiology and control.

\section{INTRODUCTION}

$r^{1}$ hagas' disease, also known as South American trypanosomiasis, is a parasitic disease caused by (Schizotrypanum) cruzi. It is endemic in Latin America occuring in 18 countries. In the American continent, human infection prevalence is estimated in 16 million cases although other 90 million, that is, $25 \%$ of the population,

\author{
Address for correspondence: \\ Dalva Marli Valério Wanderley \\ Superintendência de Controle de Endemias (SUCEN) \\ Secretaria de Estado da Saúde de São Paulo \\ Rua Paula Souza, 166 \\ São Paulo - SP - Brasil - CEP 01027-000
}

are at risk of acquiring the disease (34). In 1909 Carlos Chagas, working in the Brazilian hinterland (3), brought to light the existence of the disease, its causative agent and laid the foundations of its control measures which only after decades were put into action.

Chagas'disease has classically been considered as a tipical Latin America rural area disease. However, as a result of last decades urbanistic and industrialistic politicaleconomical models, rural-urban migration from many endemic areas has carried to the outskirts of the great cities enormous contingents of chagasic patients pressed by the lack of work in the rural zones. There are estimatives that migration carried about 300 thousand infected people to live in São Paulo and 200 thousand to Rio de Janeiro (8).

Chagas' disease social impact is very high. About 752 thousand years of productive life are lost annually due to premature deaths in South America countries. This corresponds to 1208.5 US\$ million/year (23). In Brazil, if it is considered that $10 \%$ of the infected people develop 
severe cardiac or digestive injuries, the treatment cost of such cases would amount to 250 US\$ million (8). On the other hand, the absenteism of 75,000 Brazilian chagasic workers with serious cardiac damage could represent minimum losses of US $\$ 5,250,000$ per year (7). In the State of São Paulo, where aproximately 1,500 deaths/year caused by cardiac injuries involving productive-aged individuals have been observed, there is an average loss of 23,757 working days per year (13).

\section{THE PARASITE, SYLVATIC AND DOMESTIC CYCLE, RESERVOIRS}

Trypanosoma (Schyzotrypanum) cruzi belong to the subphylum Mastigophora of the phylum Sarcomastigophora which comprises flagellates with a specialized DNA-containing organelle, the kinetoplast. $T$. cruzi is included among the stercorarian group of trypanosomes which develop in the posterior station (lower gut and rectum) of the vector and transmission is contaminative. In the vector, the parasite is found in the digestive tract, while in the vertebrate hosts it presents two different phases, hematic and cellular (34).

The sylvatic cycle of Chagas' disease results from the interaction between vectors, parasites and wild reservoirs in different natural ecotopes. The domestic cycle results from human-vector contact, involving the colonization of artificial ecotopes by the invertebrate vector (triatomines) and a series of social and ecological modifications in the environment. The parasitism, in this case, can cause important damage to the vertebrate host man - with high degrees of morbidity and mortality among infected people $(9,18)$.

The reservoirs of $T$. cruzi play important paper in both sylvatic and domestic cycles of Chagas' disease and in the interaction between them. Outstanding sylvatic reservoirs are: marsupials (opossums), edentata (armadillos), rodents (sylvatic rats and guinea-pigs), bats and other orders representatives such as primates (monkeys) and lagomorpha (rabbits and hares).

The interaction between $T$. cruzi, vectors and reservoirs may, theoretically, influence the course of the disease in humans. As a consequence of the parasite passage through different organisms, the trypanosome endures selective and adaptative processes that may result, for human beings, in strains with higher or lower morbidity potential $(18,34)$.

Humans are the main domestic reservoirs of T. cruzi, followed by cats, dogs and domestic rodents. Although not being $T$. cruzi hosts, other animals such as birds also play their part in the ecology of Chagas' disease as feeding source for a great number of triatomine species.

Besides birds, poikilothermic vertebrates such as snakes, lizards and frogs can also serve as feeding source for triatomines, a fact evidenced not only in sylvatic but in domestic environment as well $(1,9,18)$.

\section{TRANSMISSION MECHANISMS}

\section{Vectorial transmission}

The most important mechanism of transmission of $T$. cruzi to humans and other animals is throughout the feces of infected triatomines (1). The vectors of Chagas' disease are insects of the order Hemiptera, family Reduviidae and subfamily Triatominae. Of the 118 species of triatomines, only a relatively small number are epidemiologically significant as vector of $T$. cruzi as a consequence of their capacity to domicilize: Triatoma infestans, $T$. braziliensis, $T$. dimidiata, $T$. sordida, Panstrongylus megistus and Rhodnius prolixus. The geographic distribution of the main vectors of Chagas'

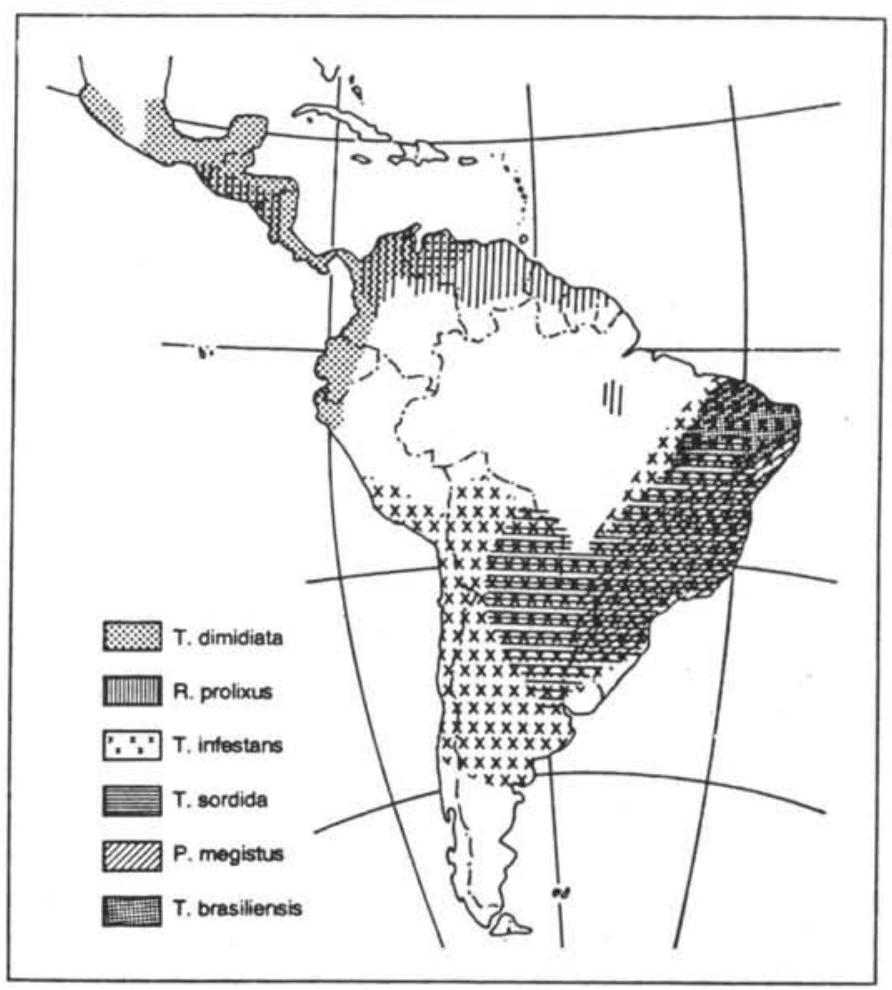

Figure 1. Geographic distribution of the main T. cruzi triatomine vectors. 
disease is depicted in Figure 1. From Mexico to Venezuela and Colombia, $R$. prolixus and $T$. dimidiata are the main vectors while south of the Equator line, $T$. infestans is undoubtedly the outstanding source of the disease for humans. The Amazon region appears as a barrier between southern and northern endemic regions despite the existence of wild vectors and reservoirs troughout the forest $(8,9,11,25)$. Such species are characteristic of the so called open spaces of South and Central America, being them natural or the result of anthropic action (7). The rate of $T$. cruzi transmission will be dependent on several factors, including vectors density, food source preference, longevity, susceptibility to different parasite strains, capacity to defecate immediately after the blood meal, and ability to yield and eliminate large quantities of parasites $(1,34)$.

\section{Transfusional transmission}

The possibility of transfusion transmitted Chagas' disease was first raised in Argentina, in 1936 (15). In 1944 it was formally mentioned as a public health problem in Latin America (6). The first infected donors were recorded in 1949, and in 1952 the first cases of the transfusional disease in São Paulo, Brazil (12) were reported. An updated large review (22) refers to the various surveys conducted in blood banks all over the American continent in the last decade showing prevalence rates varying between $0 \%$ and $63 \%$, with an approximate mean of $3 \%$. Bolivia is the country with higher prevalence of infected donors.

These data become very important when studies that show percentages of $60 \%$ among cronic chagasic patients that present blood-circulating T. cruzi are considered and that the risk of acquiring a chagasic infection via an infected donor goes from $12.5 \%$ to $25.0 \%$ for only one transfusion (33). If it is considered that yearly more than 4 million blood transfusions are performed in Brazil, it is probable that many thousand infections may be transmitted in such a way (34). Such estimate must be looked at with care since it is based on not-at-all examined blood samples which presently are less seen in Brazil.

Only 284 cases were found in a revision of the literature on transfusional Chagas' disease cases reported in the last 40 years and they securely represent a minority among really occurring cases (33). Factors associated to the parasite and to the receptor, the number of transfusions received by the patient and the prevalence of the infection in the zone under study keep relation with the risk of blood transfusion transmission of Trypanosoma cruzi. Another risk factor is the viability of the parasite, that is, its capacity for causing infection even when stored up to 3 weeks under low temperatures.

\section{Congenital transmission}

The first observation on the possibility of congenital Chagas' disease transmission was made in 1911 (10). In 1949 the first human case was described and the parasite observed in a thick blood film of a 2-day-old newborn whose mother did not present positive xenodiagnosis. From then on several reports were presented $(10,34)$. A literature revision performed in 1987 detected 200 clinically comproved cases. Prematurity was often included among clinical aspects (16). Studies on the frequency of Chagas' disease among pregnant women in Brazil showed a variation from $4 \%$ to $16.4 \%$ while the illness incidence among newborn varied from $16 \%$ to $10.5 \%$ (10). Congenital transmission in Brazil may not be underestimated if, with the accepted risk of $1 \%$ it is considered that 750 thousand chagasic women in fertile age may originate 7.500 congenitally transmitted cases $(8,10)$ each year.

In Argentina studies indicated prevalence from 6\% to $20 \%$ among pregnant women according to the area's endemicity. In Santa Cruz, Bolivia, it was 51\%. In Santiago do Chile and 3 other Chilean localities situated in endemic areas, the seropositivity in pregnant women varied from $0.8 \%$ to $7.4 \%$. In Artigas, Uruguay, it was $8.9 \%$.

The majority of the infected women which gave birth to children presenting congenital chagasic infection do not show clinical symptons of Chagas' disease chronic form. The infection does not seem to interfere neither with the fecundity nor with the pregnancy evolvement. Differences between groups of infected and non-infected mothers concerning abortion, newborn low weight, premature birth, intra-uterine disorders and fetal development have not been observed.

Cases of congenital Chagas' disease have been reported in Argentina, Bolivia, Brazil, Chile, Uruguay and Venezuela. In Argentina, the prevalence of the congenital infection oscilates from $0.75 \%$ to $3.50 \%$. In Bahia, Brazil, the prevalence was $10.5 \%$; in Chile, $18.8 \%$; in Uruguay $1.57 \%$ and in Santa Cruz, Bolivia, it ranged from $5 \%$ to $8 \%(34)$.

\section{Oral transmission}

There are 3 reports of oral transmission of Chagas' disease to human beings: an epidemic outbreak in Teutônia, Rio Grande do Sul, with 17 persons simultaneously infected, probably due to the ingestion of contaminated meal with urine from infected marsupials (26); another in Pará, Brazil, where 4 persons seem to have been infected through the ingestion of food contaminated with triatomine excreta (24); and, more recently, an outbreak in Paraíba State, when 28 individuals acquired acute Chagas' disease 
following the ingestion of sugar-cane juice probably contaminated with triatomine feces (14).

\section{Transmission by breast-feeding}

This kind of T. cruzi transmission was first suspected in 1936 (16). Trypomastigote isolation from infected mothers' colostrum is a rare occurrence. Thus, transmission by breast-feeding seems very unlikely and there is no reason to restrict breast-feeding by infected mothers.

\section{Accidental transmission}

Although occurring very seldom, laboratorial contamination represents a serious risk of acquiring Chagas' disease. It can occur very often as a consequence of puncture with contaminated needles, contact of the conjuntiva with contaminated material and while pippetting $T$. cruzi cultures. There are about 50 cases reported all around the world in different developed and underdeveloped countries (34).

\section{Transmission by organ transplantation}

T. cruzi may be transmitted by organ transplantation from infected donors. Receptors suffer illness episodes and the parasites may be isolated from peripheral blood (4). A few fatal cases have been reported in which the parasites have been isolated from different organs. As organ receptors are submitted to immunesuppressive therapy their susceptibility to infections tends to increase. In the same way, chronic chagasic recipients may present a worsening of the infection as a consequence of the immunosuppressive treatments. The most frequent situation recorded involves kidney transplants (with more than 10 cases described) but cases of transmission in heart and pancreas transplants have been reported as well (10).

\section{HUMAN CHAGAS' DISEASE}

\section{Geographic Distribution}

The geographic distribution of $T$. cruzi human infection goes from the south of the United States of America - where sporadic cases have been reported - to the south of Argentina (Figure 2).
Endemic countries may be divided into 4 groups according with the transmission magnitude, the quantity and the quality of the epidemiological information available and the existence or not of Control Programmes (35) (Table 1).

In Brazil, the endemic area comprises more than $3,500,000 \mathrm{~km}^{2}$, that is, $44.5 \%$ of the national territory, being the larger in the Americas. It involves 2,450 municipalities from the following States: Alagoas, Bahia, Ceará, Espírito Santo, Goiás, Maranhão, Mato Grosso do Sul, Minas Gerais, Paraíba, Paraná, Pernambuco, Piauí, Rio de Janeiro, Rio Grande do Sul, Rio Grande do Norte, São Paulo, Sergipe and Distrito Federal (8). Recently, autochthonous cases were reported from the States of Pará, Amazonas, Amapá and Acre (5).

In practical terms, the human disease presents great difficulties for specific therapy in its chronic phase and the inexistence of a largely safe and sound vaccine has led the sanitary authorities to priorize control actions against vectorial transmission $(7,21)$ and prevention of transfusional transmission. The previous selection of infected donors and chemoprophylaxis have produced positive results wherever they have been used $(19,22,32)$.

The Chagas' Disease Vectorial Control National Programme initiated in 1950, reached its larger coverage by 1983. In 1986, when it was fully consolidated, the impact was highly positive with drastic reduction of the triatomine-trypanosomic rates over all the endemic area

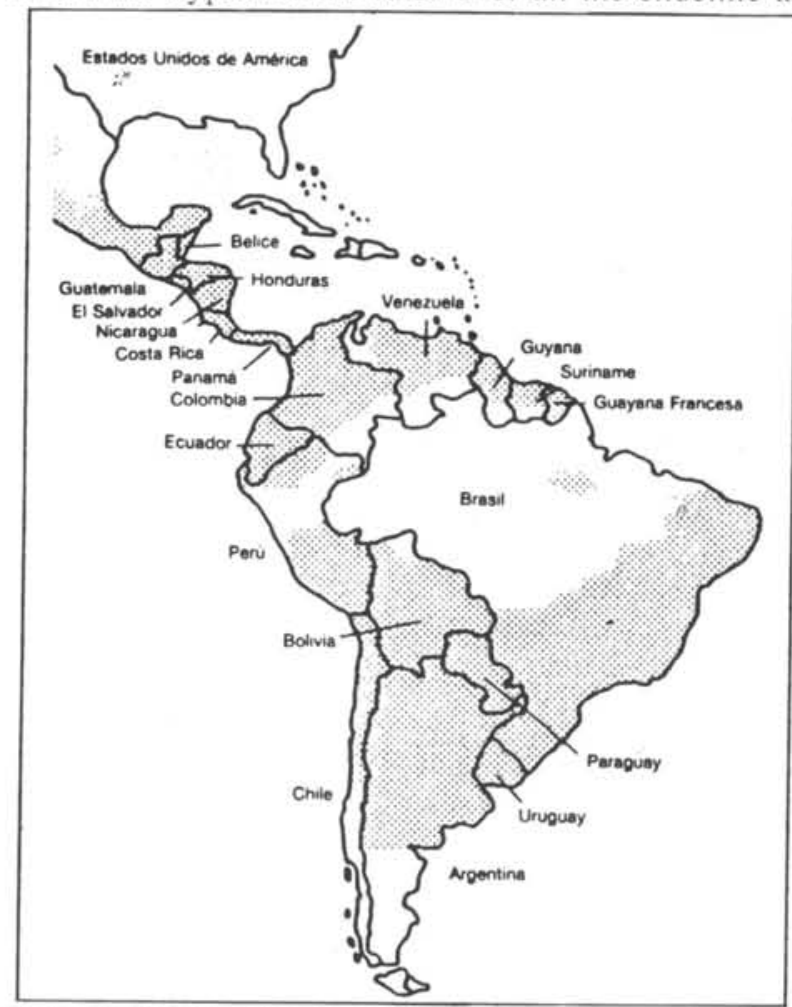

Figure 2. Geographic distribution of T. cruzi human infection in the Americas. 
Table 1

Prevalence of $T$. cruzi human infection in Latin America, 1980-1985.

\begin{tabular}{|c|c|c|c|c|}
\hline \multirow[t]{2}{*}{ Endemic Countries } & \multicolumn{2}{|c|}{ Population at risk } & \multicolumn{2}{|c|}{ Population infected } \\
\hline & $n^{2} \times(1000)$ & $\%(")$ & $n^{0} \cdot x(1000)$ & $\%\left({ }^{*}\right)$ \\
\hline \multicolumn{5}{|l|}{ Group I } \\
\hline Argentina & 6900 & 33 & 2640 & 38 \\
\hline Brazil & 41054 & 32 & 6340 & 26 \\
\hline Chile & 1800 & 15 & 1460 & 81 \\
\hline Ecuador & 3823 & 41 & 30 & 1 \\
\hline Honduras & 1824 & 42 & 300 & 16 \\
\hline Paraguay & 1475 & 45 & 397 & 27 \\
\hline Peru & 6676 & 34 & 643 & 10 \\
\hline Uruguay & 975 & 33 & 37 & 4 \\
\hline Venezuela & 11392 & 68 & 1200 & 11 \\
\hline \multicolumn{5}{|l|}{ Group II } \\
\hline Bolivia & 1800 & 30 & 500 & 28 \\
\hline Colombia & 3000 & 10 & 900 & 30 \\
\hline Costa Rica & 1112 & 45 & 130 & 12 \\
\hline Mexico & - & - & - & - \\
\hline \multicolumn{5}{|l|}{ Group III } \\
\hline El Salvador & 146 & 43 & 322 & 15 \\
\hline Guatemala & 4022 & 52 & 730 & 18 \\
\hline Nicaragua & - & - & - & - \\
\hline Panamá & 898 & 42 & 220 & 24 \\
\hline Total & 86897 & 25 & 15849 & 18 \\
\hline
\end{tabular}

(*) As \% of total population / (*) As \% of population at risk Source: WHO, 1990 (24).

(7). Such success was attained with residual insecticides through an intensive house-spraying work. In the beginning $\mathrm{BHC}$, a representative of the organochlorine, was the insecticide of choice as studies showed its high efficacy against $T$. infestans, its relatively low costs and its moderated toxic effects. From the beginning of the 80 's pyretrhoids with greater residual effects and less toxic to humans were proposed as substitutes of the BHC (27) which was soon abandoned. By 1991, the main domestic vector T. infestans had been eliminated from $32.3 \%$ of the Brazilian municipalities. Notwithstanding, despite $T$. infestans residue, results obtained in the searched area show dwelling infestation rates lower than $2 \%$ which is an indicative that vectorial transmission possibilities are nowadays extremely reduced in the country (6).

It seems interesting to note that the vectorial control programmes employing such a model - spraying of houses with residual insecticides - attained interruption of Chagas' disease transmission when $T$. infestans house infestation rates under $5 \%$ were reached (2).

In the State of São Paulo, Chagas' disease vector control, started in 1950, attained full success two decades later $(2,21,28)$. Nowadays it is kept epidemiological surveillance on secondary species - T. sordida and $P$. megistus. The results obtained in the last 10 years indicate strong presence of those vectors in the peridomicile (70\%), low percentage of $T$. cruzi natural infection $(2.4 \%)$ and discrete proximity towards humans as only $5 \%$ of the captured specimens have fed on such hosts. The prevalence of chagasic infection in the inhabitants of houses infected with triatomines was $3.2 \%$, and the concentration of positives in individuals older than 20 years of age. Such information confirm the absence of natural transmission by Chagas' disease triatomine vectors. In this surveillance, population is having important role in the notification of intradomicile focus. Each notification is answered by the 
control organism with a carefull search of the domicile unit which has as objetives evaluate focus extent and, when necessary, use insecticides. Quick answer to each notification feeds back the process and ensures control over the area $(29,30,31)$.

Although vectorial transmission is under control in São Paulo State and large areas in Brazil, there is no infrastructure to assist the infected individual detected by the programme. This aspect has a large importance and has worried those responsible for the official control institutions $(7,28,29)$.

\section{Natural history}

T. cruzi human infection may occur under different ways according to circunstances and situations. Hostparasite interaction is quite dynamic and depends on multiple factors related with the trypanosome (strain, virulence, inoculum), the human host (age, sex) and the environment. As a rule, the existence of two different distinct phases of the disease is accepted: the acute and the chronic, each one of them presenting different characteristics.

\section{Morbidity}

As it is known, an individual infected with $T$. cruzi will not necessarily present any aparent clinical form of the disease. This also happens specifically during the acute phase in which the great majority of the cases will go unseen. The hypothesis of acute disease, despite the frequently discrete picture, must impose itself in the endemic regions and in pos-transfusional situations.

The large majority of the individuals will be assimptomatic during the disease first 10 or 20 years. In general, the indeterminate or subclinical form of Chagas' disease persists in at least $30 \%$ of the chagasic patients for their entire life. This indeterminated form is generally defined by the presence of positive serology for T. cruzi in an asymptomatic patients and no electrocardiographic and radiological abnormalities. A great importance of this form of the disease is that patients keep and must keep a totally normal life as they are apts for almost all tasks and jobs. The only work restriction for indeterminated form patients, according to the specialists, refer to professions that can offer risk to the life of others, as drivers in general, machine operators, aircraft pilots and so on. Among the clinical forms of the chronic phase cardiopathy, esophagophathy and colopathy are the most important.

Chronic chagasic cardiopathy is the most important of the clinical forms of the disease not only for its prevalence but mainly due to the seriousness of the damage it may produce. This lesion is more frequent in men and strikes progressively from the third decade of life on.
The digestive forms, specially esophagopathy and colopathy are relatively commons. Esophagopathy presents higher prevalence in males in a percentage of $6 \%$ to $8 \%$ for the regions of Bahia and Minas Gerais. Colopathy is a late manifestation of chronic Chagas' disease appearing predominantly after the fourth or fifth decades of life. Other portions of the digestive tube may also be affected but less frequently $(9,18)$.

\section{Mortality}

Mortality in Chagas' disease is very significative in several endemic countries such as Brazil, Argentina, Bolivia, Venezuela and North of Chile, depending basically on the incidence of severe cardiopathy (34).

In Brazil, according to official statistics, at least 6,000 deaths/year due to Chagas' disease have been recorded (17), figures that demonstrate the importance of the disease from the medical and social standpoints.

Examining the mortality coefficients caused by Chagas' disease in four of the endemic Brazilian states, calculated for each 100 thousand inhabitants in the years from 1977 and 1987, a significant reduction may be observed. Thus, for Minas Gerais, São Paulo, Paraná and Bahia the values felt from 17.7, 6.9, 5.1 and 4.2, in 1977, to respectively, 13.0, 4.7, 4.1 and 3.9, in 1987.

From 1977 to 1986, in São Paulo State, a mean number of 1,537 annual deaths in which Chagas' disease was identified as the basic cause were observed. The participation of the American trypanosomiasis in the proportional mortality ranged to $0.9 \%$; specific values for each year varying from 1,455 to 1,615(13). A survey based on the death certificates in São Paulo State, in 1987, verified that out of 1,646 statements in which Chagas' disease was mentioned, it was considered the main cause of the death in 1,516 and it participated in 130 as a contributory cause. It was observed that men died more frequently of Chagas'disease than women and that the proportion of the deceased raised with age. The region of the Great São Paulo concentrates a larger number of deaths attributed to Chagas' disease.

Cardiac failure was observed in $91 \%$ of the deaths. In this study it was possible to confirm the importance of Chagas' disease in the State and to point out information that contributed to the planning of attendance to the chagasic patient.

\section{FINAL CONSIDERATIONS}

Available epidemiological data indicate that Chagas' disease is an important medical and social problem in large 
extensions of Latin America. This picture is worsened due to the inexistence of vectorial control programmes and blood control policies in many countries, since the priority to transfusional Chagas' disease has not been established in many endemic regions. Only when AIDS became a major problem countries such as Argentina, Brazil, Uruguay and Venezuela decide to settle control policies (22). In Brazil, a survey carried out in 850 municipalities, from 1988 to 1990 , indicated that Chagas' disease previous screening was performed in $66.9 \%$ of the hemotherapic services (19). From these, $55.3 \%$ performed only one serological test for the donor screening, despite the official recommendation for the use of at least two screening techniques (34).
Implementation and maintenance of regular vector control programmes, whose cost-benefit relation speeks highly in favour of the investment (23) and the amelioration of the hemotherapic sector, must lead to the triatomine vector domiciliary transmission and to the transfusional transmission control in the future. The congenital disease and other even more rare forms of $T$. cruzi transmission to humans ought to be exceptional.

Infected individuals, with or without clinical manifestations, must receive medical and previdenciary attention, resting to the State to cope with such demands, according to the precepts established in the last Brazilian constitutional law.

\section{Resumo}

A doença de Chagas constitui um importante problema de saúde pública para a América Latina, afetando 16 milhōes de pessoas e expondo ao risco de adquirir a infecção outros 90 milhões. Uma vez conhecidos os aspectos epidemiológicos da doença, foi possivel delinear, nas últimas quatro décadas, as ações de controle da sua transmissāo vetorial, cuja estratégia não foi adotada em todos os paises da área endêmica. A migraçāo rural-urbana fez emergir a transmissão por meio da transfusão de sangue nos centros urbanos, fazendo surgir milhares de novos casos da doença.

No Brasil, o programa nacional alcançou grande êxito na última década, eliminando a transmissão vetorial em vários estados.

Mais recentemente, foi definida uma política para o setor hemoterápico ainda incipiente, que, se implementada, deverá eliminar por completo essa via de disseminaçāo de Trypanosoma cruzi refletindo diretamente nas outras formas mais raras de transmissão. A atençāo médica aos indivíduos infectados deve ser devidamente estruturada de modo a diminuir o custo social da doença na sua expressão clínica mais grave, a cardiopatia chagásica, que tem reduzido a expectativa de vida de grande contingente de indivíduos em fase produtiva.

\section{REFERENCES}

1. BARRETO, M.P. - Epidemiologia. In: Brener Z, Andrade Z. eds. Trypanosoma cruzi e doença de Chagas. Rio de Janeiro, Guanabara Koogan, 1979. p. 89-151.

2. BURALLI, G.M. - Estudo do controle dos triatomíneos domiciliados no Estado de São Paulo. São Paulo 1985. 240 p. (Dissertação de mestrado Fac. Saúde Pública USP).

3. CHAGAS, C. - Nova tripanozomiase humana. Estudos sob a morfologia e o ciclo evolutivo do Schizotrypanum cruzi n.gen.,s.sp. agente etiológico de nova entidade mórbida do homem. Mem Inst Oswaldo Cruz 1: 159-218, 1909.

4. CHOCAIR, P.R.; SABBAGA, E.; AMATO NETO, V.; SHIROMA, M. \& GOES, G.M. - Nova modalidade de transmissão da doença de Chagas. Rev Inst Med trop São Paulo 23: 280-282, 1981.

5. COURA, J.R. - Doença de Chagas na Amazônia brasileira. Rev Soc Bras Med Trop 26 (supl 2): 15-7, 1993.

6. DIAS, J.C.P. - A doença de Chagas e seu controle na América Latina. Uma análise de possibilidades. Cad Saúde Públ, Rio de Janeiro 9: 201-9, 1993. 
7. DIAS, J.C.P. - Control of Chagas Disease in Brasil. Parasitol. Today 3: 36-41, 1987.

8. DIAS, J.C.P. - Epidemiology of Chagas Disease in Brazil. In Brener, R.R. \& Stoka, A.M. eds. Chagas'Disease Vectors. Boca Raton, CRC Press Inc 1: 57-81, 1987.

9. DIAS, J.C.P. - Epidemiology of Chagas disease. In: Wendel, S.; Brener, Z.; Camargo, M.E. \& Rassi, A. eds. Chagas Disease (American Trypanosomiasis) its impact of transfusion and clinical medicine. São Paulo, ISBT 1992. p. 49-80.

10. DIAS, J.C.P. - Mecanismos de transmissão In: Brener, Z. \& Andrade, Z. eds. Trypanosoma cruzi e doença de Chagas. Rio de Janeiro, Guanabara-Koogan, 1979. p. 152-174.

11. FORATTINI, O.P. - Biogeografia, origem e distribuição da domiciliação de triatomíneos no Brasil. Rev Saúde Públ São Paulo 14: 205-29, 1990.

12. FREITAS, J.L.P.; AMATO-NETO, V.; SONNTAG, R.; BIANCALANA, A.; NUSSENZWEIG, V. \& BARRETO, J.G. - Primeiras verificações da transmissão acidental da moléstia de Chagas ao homem por transfusão de sangue. Rev Paulista Medicina 40: 36-40, 1952.

13. LITVOC, J.; WANDERLEY, D.M.V. \& ARANHA CAMARGO, L.M. - Mortalidade por doença de Chagas no Estado de São Paulo (Brasil):Subsídios para o planejamento da assistência ao chagásico. Rev Saúde Públ São Paulo 26: 59-65, 1992.

14. MARCONDES, C.B.; GUEDES, L.A. \& MENDONÇA, D. - Surto de doença de Chagas de provável contaminação oral em Catolé do Rocha (Pb):observações epidemiológicas. Rev Soc Bras Med Trop 20(supl.2): M11-3, 1987.

15. MAZZA, S.; MONTANA, A.; BENITEZ, C. \& JUZIN, E. Transmisión del Schizotrypanum cruzi al niño por leche de la madre con enfermedad de Chagas. Mis Est Pat Reg Arg 28: 41-6, 1936.

16. MENEGUETTI, L.C. - Epidemiologia da transmissão congênita da doença de Chagas: subsídios para a formulação de um projeto de pesquisa. São Paulo, 1986. 130 p. [Dissertação de Mestrado, Fac. Saúde Pública USP].

17. MINISTÉRIO DA SAÚDE - Estatísticas de Mortalidade. Brasilia. 1987.

18. MINISTÉRIO DA SAÚDE - Superintendência de Campanhas de Saúde Pública-SUCAM. Doença de ChagasClínica e Terapêutica. Brasilia 1990 .p. 1-94.

19. MORAES-SOUZA, H.; WANDERLEY, D.M.V.; BRENER, S.; NASCIMENTO, R.D. \& DIAS, J.C.P. - Situação da doença de Chagas transfusional e da hemoterapia no Brasil. Resultados de um inquérito nacional. Bol Of Sanit Panam 116: 406-19, 1994.

20. PELLEGRINO, J. - O perigo da transmissão da doença de Chagas pela transfusão de sangue. Primeiras comprovações sorológicas de esquizotripanose em doadores e em candidatos a doadores de sangue. Brasil Med 63: 65-71, 1949.
21. ROCHA E SILVA, E.O.; GUARITA, O.F. \& CORRÊA, R. Doença de Chagas. Atividades de controle dos transmissores no Estado de São Paulo. Rev Bras Malar 31: 99-119, 1979.

22. SCHMUNIS, G.A. - Trypanosoma cruzi, the ethiologic agent of Chagas disease:Status in the blood supply in endemic and nonendemic countries. Transfusion 31: 547-57, 1991.

23. SCHOFIELD, C.J. \& DIAS, J.C.P. - A cost benefit analysis of Chagas disease control. Mem Inst Oswaldo Cruz 86: 285-95, 1991.

24. SHAW, J.; LAINSON, R. \& FRAHIA, H. - Considerações sobre a epidemiologia dos primeiros casos autóctones de doença de Chagas registrados em Belém, Pará, Brasil. Rev Saúde públ 3: 153-57, 1969.

25. SHERLOCK, I.A. - Vetores In: Brener, Z. \& Andrade, Z. Trypanosoma cruzi e Doença de Chagas. Rio de Janeiro: Guanabara-Koogan 1979. 83 p.

26. SILVA, N.N.; CLAUSELL, D.T.; NOLIBUS, H.; MELLO, A.L.; OSSANAI, A.; RAPONE, T. \& SNELL, T. - Surto epidêmico de doença de Chagas com provável contaminação oral. Rev Inst Med trop São Paulo 10: 265-76, 1969.

27. SILVEIRA, A.C. \& SAKAMOTO, T. - Importância médicosocial da doença de Chagas no Brasil e seu controle. Rev brasil malariol D trop 35: 127-134, 1983.

28. SOUZA, A.G.; WANDERLEY, D.M.V.; BURALLI, G.M. \& ANDRADE, J.C.R. - Consolidation of the control of Chagas disease in the State of São Paulo. Mem Inst Oswaldo Cruz 79(supl): 125-132, 1985.

29. WANDERLEY, D.M.V. - Análise da atual estratégia do Programa de Controle da doença de Chagas no Estado de São Paulo. São Paulo, 1987. 103 p. [Dissertação de mestrado, Fac.Saúde Pública USP].

30. WANDERLEY, D.M.V. - Vigilância do risco de transmissão da doença de Chagas por vetores secundários no Estado de São Paulo. Rev Soc Bras Med trop 26: 38-40, 1993.

31. WANDERLEY, D.M.V. - Vigilância entomológica da doença de Chagas no Estado de São Paulo. Rev Saúde públ S Paulo 25: 28-32, 1991.

32. WANDERLEY, D.M.V.; GONZALES, T.T.; PEREIRA, M.S.C.A.; NASCIMENTO, R.D. \& MORAES-SOUZA, H. - Controle da hemoterapia e da doença de Chagas transfusional no Estado de São Paulo: 1988 e 1990. Rev Saúde públ. S.Paulo 27: 430-5, 1993.

33. WENDEL, S. \& DIAS, J.C.P. - Transfusion transmitted Chagas disease. In: Wendel, S.; Brener, Z.; Andrade, Z. \& Rassi, A. eds. Chagas disease (American Trypanosomiasis) its impact on transfusion and clinical medicine. São Paulo: ISBT, 1992. p. 103-133.

34. WHO - Control of Chagas disease. WHO Technical Report Series 811, World Health Organization, Geneva, 1991. 95p. 35. WHO - Wkly. Epidem Rec 65: 257-64, 1990. 